\title{
Sourcing Lifecycle for Software as a Service (SAAS)
}

\author{
Santy $^{1}$, K. Sikkel ${ }^{2}$ \\ ${ }^{1}$ Bina Nusantara University, School of Information System, 11480 Jakarta, Indonesia \\ ${ }^{2}$ University of Twente, Faculty of Electrical Engineering, Math and Comp. Science, 7500AE Enschede, The Netherlands
}

\begin{abstract}
In recent years, Software as a Service (SaaS) has changed from curiosity caused concept to an accepted well known concept. A key advantage of this model is that, by cautious engineering, it is possible to influence economy of scale to decrease total cost of ownership compared to on-premises solutions. By using the guideline elaborated in this paper, companies which has interest in implementing SaaS will be led throughout the entire implementation cycle starting before the company decides to implement SaaS until the stage when the company decides to shift from SaaS model to another model or when they shift to another SaaS company
\end{abstract}

\section{Introduction}

Software as a Service or often called as SaaS, is one of the sourcing models currently out there in the market for companies who want to outsource its IT services. In the last few years, it has emerged to an accepted mainstream concept and is regarded as a favorable solution used to enhance a modern organization's IT performance and competitiveness [1]. A key advantage of this sourcing model is that, by cautious engineering, it is possible to influence the economy of scale to decrease total cost of ownership (TCO) compared to on-premises solutions. The model, which promises lower TCO and plug and play implementation has teased companies to implement SaaS, replacing their on-premises solutions. A major technological attribute of SaaS is that software and data are provided from a central server to multiple tenants directly through multi-tenancy technology [2].

SaaS or also known as on-demand software is an application owned, delivered and also managed remotely by one or more providers, where the provider delivers an application based on a single set of common code and data definitions which are consumed in a one-to-many model by all contracted customers at any time on a payfor-use basis or as a subscription based on use metrics [3]. So SaaS provides advantages to give service to customers with no initial cost to purchase software, free of maintenance/updates, accessibility through Internet, high availability, and pay-per-use pricing [4]. SaaS users are able to use various software products on demand, including ERP, CRM and SCM [5]. Instead of software licenses, maintenance and operational costs which occur in the traditional on premise model, companies that apply SaaS model consumes IT-services just like consuming any other utilities such as water or electricity where they will pay only for the usage of the software. In the SaaS model, the supplier delivers the bundle of IT infrastructure, software applications, and also services to users through a network.

In this paper, we provide a generic sourcing lifecycle recommended for companies to achieve a successful implementation of SaaS application. To this conclusion we conducted a theories overview and practical literature, and design a Sourcing lifecycle for a SaaS implementation.

\section{Sourcing Lifecycle}

Outsourcing activities often grouped in to several groups. These grouping appear with the form of a lifecycle. Reference [6] defines the outsourcing lifecycle into seven phases:

1. Determine the business case for or against outsourcing

2. Search for vendors

3. Select a vendor

4. Conduct negotiations

5. Consummate an agreement

6. Manage the agreement

7. Determine the business case to decide whether to renew, renegotiate or terminate the contract.

Another general lifecycle defined is from [7] where they defined 4 sets of phases consisting in total 9 building blocks. These phases and building blocks are:

1. Architect phase, where the foundation of the outsourcing is defined. Reference [7] later on defined further building blocks for this phase as: Investigate, Target, Strategize, and Design. The 
final expected outcome of this phase is that the organization will understand correctly what the company's needs are, so they can bring out these needs to the market.

2. Engage phase, in this phase one or more suppliers will be selected and the deal is negotiated. This phase consists of Select and Negotiate building blocks.

3. Operate phase, in phase the deal is put in place, operationalised and managed through its terms. The building blocks for this phase are Transition and Manage.

4. Regenerate phase, in this last phase, the next generation options are assessed. This phase only consists of one building block which is Refresh.

In her research, [8] defines the outsourcing lifecycle consisting 5 phases which are:

1. Identify business and its needs. During this phase the business requirements and wishes are identified. The main questions of this phase are whether or not to outsource and if yes, what to outsource. Another point that needs to be confirmed in this phase is what the objectives of the outsourcing strategy are.

2. Select supplier(s). In this phase, the selection of the most suitable supplier is being performed. The examples of the activities covered in this phase are the determination of criteria, sending out requests for proposals (RfPs), negotiations and the final selection itself.

3. Transition. In this phase, the actual transition of work to the customer is being done. This phase may include pilots to determine the best way to collaborate together.

4. Manage outsourcing relationship. This phase is about managing the relation between the supplier and the client organization. The phase starts when the supplier delivers the service until the expiration time of the contract.

5. Evaluate and renew or terminate. In this last phase, the client organization decides whether to renew the contract with the supplier or the opposite, terminate the contract.

While [9] defined IT outsourcing life cycle covering the key problem domains along the process of:

1. Making the sourcing decision

2. Arranging the outsourcing relationship

3. Managing the outsourcing relationship

4. Changing or renewing the relationship based on a recurrent evaluation of the outcome of the relationship.

Lastly, in their paper, [10] defined 6 phases of IT outsourcing:

1. Planning

2. Analysis

3. Design

4. Implementation

5. Operations

6. Termination

From these five views of lifecycles above, [11] concluded that the sourcing lifecycle consists of 5 phases:

1. Business Strategy
2. Supplier Selection

3. Transition

4. Manage Relationship

5. Evaluate, renew or terminate

Table 1 depicts the five views of sourcing lifecycle.

Next, we discuss each phases of Sourcing Lifecycle

1. Business Strategy

In this initial phase, the needs of the business will be identified and requirements based on these needs will be formulated $[8,10]$. The next step is the identification of risks which can occur by outsourcing the application [10]. Furthermore an evaluation of existing outsourcing models will be conducted and a decision of which outsourcing model chosen will be made [7]. Therefore it is extremely important for the business to understand the characteristics, pros and cons of the outsourcing options so they can understand the costs and benefits that the outsourcing model will bring to the organization. In this phase, a business case is built and a demand forecasting is made [7]. All of the five authors confirm the need of this initial phase.

\section{Supplier Selection}

After deciding which type of outsourcing which will be implemented, organization needs to explore and decide which supplier can match their business needs. The phase started with determining criteria for the supplier and sending out requests for proposals (RfP) and then negotiations and final selection of the supplier. In this phase, the contract is being arranged. We propose that the Design building block from [7] is part of this phase since in this building block, the scorecard, SLA draft, draft price model, draft contract are arranged and this is the phase when contract management process starts. The goal of Contract Management process is to facilitate contracts throughout all phases of the outsourcing lifecycle [8]. Contract Management process starts from the phase when the contract is being arranged until the contract ends.

3. Transition

Reference $[6,9]$ did not discuss about the transition phase in their lifecycle while $[7,8,10]$ have considered the Transition phase as one of the phase in their sourcing lifecycle. We argue that Transition is one of the sourcing lifecycle phases, where it is the phase when the negotiation with the selected supplier is being done and also the phase where actions are being done by the customer organization and supplier for preparing the delivery of the service. In this phase, the contractual documents and negotiation strategy and items are being arranged [7]. After an effective negotiation, the finalization and contract signing is also done in this phase [7]. Transition is the phase where a project is generally being set up to implement the services. In this phase the integration of the new service with the existing services in the client organization is done and all plans such as communication, risk, setup and acceptance are finalized and mobilized [7]. The next steps are the transfer itself (works in progress 3rd party contracts, etc), the knowledge retention and transfer, implement retained organization and contract management and lastly, when all of the transition is finished, an acceptance and post implementation review will be performed [7]. 
Table 1. Five views of sourcing lifecycle. [11]

\begin{tabular}{|c|c|c|c|c|c|}
\hline Phases & Reference [6] & Reference [7] & Reference [8] & Reference [9] & Reference [10] \\
\hline $\begin{array}{l}\text { Business } \\
\text { strategy }\end{array}$ & $\begin{array}{l}\text { 1. Determine } \\
\text { the business } \\
\text { case for or } \\
\text { against } \\
\text { outsourcing }\end{array}$ & $\begin{array}{l}\text { 1. Investigate } \\
\text { 2. Target } \\
\text { 3. Strategize }\end{array}$ & $\begin{array}{l}\text { 1. Identify } \\
\text { business and } \\
\text { its needs }\end{array}$ & $\begin{array}{l}\text { 1. Making the } \\
\text { sourcing } \\
\text { decision }\end{array}$ & $\begin{array}{l}\text { 1. Initiation of sourcing } \\
\text { evaluation } \\
\text { 2. Analysis of current } \\
\text { systems and changes } \\
\text { 3. Identification of objectives } \\
\text { 4. Estimation of efforts } \\
\text { 5. Identification of core } \\
\text { competencies } \\
\text { 6. Identification of risks } \\
\text { 7. Staff arrangement } \\
\end{array}$ \\
\hline $\begin{array}{l}\text { Supplier } \\
\text { selection }\end{array}$ & $\begin{array}{l}\text { 1. Search for } \\
\text { vendors } \\
\text { 2. Select a } \\
\text { vendor }\end{array}$ & $\begin{array}{ll}\text { 1. } & \text { Design } \\
\text { 2. } & \text { Select }\end{array}$ & $\begin{array}{ll}\text { 1. } & \text { Select } \\
\text { supplier(s) }\end{array}$ & $\begin{array}{l}\text { 1. Arranging } \\
\text { the } \\
\text { outsourcing } \\
\text { relationship }\end{array}$ & $\begin{array}{l}\text { 1. Preparation of request for } \\
\text { proposal } \\
\text { 2. Identification of potential } \\
\text { suppliers } \\
\text { 3. Distribution of request for } \\
\text { proposal } \\
\text { 4. Determination of criteria } \\
\text { 5. Selection of supplier }\end{array}$ \\
\hline Transition & $\begin{array}{l}\text { 1. Conduct } \\
\text { negotiations }\end{array}$ & $\begin{array}{l}\text { 1. Negotiate } \\
\text { 2. Transition }\end{array}$ & 1. Transition & - & $\begin{array}{l}\text { 1. Determination of } \\
\text { outsourcing relationship } \\
\text { 2. Determination of contract } \\
\text { type } \\
\text { 3. Preparation of contracts } \\
\text { 4. Transfer of business logic } \\
\text { 5. Transfer of systems, } \\
\text { specifications, and } \\
\text { documentation }\end{array}$ \\
\hline $\begin{array}{l}\text { Manage } \\
\text { Relations } \\
\text { hip }\end{array}$ & $\begin{array}{ll}\text { 1. Consummat } \\
\text { e an } \\
\text { agreement } \\
\text { 2. Manage the } \\
\text { agreement }\end{array}$ & 1. Manage & $\begin{array}{l}\text { 1. Manage } \\
\text { outsourcing } \\
\text { relationship }\end{array}$ & $\begin{array}{l}\text { 1. Managing } \\
\text { the } \\
\text { outsourcing } \\
\text { relationship }\end{array}$ & $\begin{array}{l}\text { 1. Measurement of } \\
\text { compliance to requirements } \\
\text { 2. Enforcement of } \\
\text { compliance }\end{array}$ \\
\hline $\begin{array}{l}\text { Evaluate, } \\
\text { renew or } \\
\text { terminate }\end{array}$ & $\begin{array}{l}\text { 1. Determine } \\
\text { the business } \\
\text { case to } \\
\text { decide } \\
\text { whether to } \\
\text { renew, } \\
\text { renegotiate } \\
\text { or terminate } \\
\text { a contract. }\end{array}$ & 1. Refresh & $\begin{array}{l}\text { 1. Evaluate and } \\
\text { renew or } \\
\text { terminate }\end{array}$ & $\begin{array}{l}\text { 1. Changing or } \\
\text { renewing the } \\
\text { relationship }\end{array}$ & $\begin{array}{l}\text { 1. Preparation for early } \\
\text { termination } \\
\text { 2. Evaluation of final software } \\
\text { products }\end{array}$ \\
\hline
\end{tabular}

4. Manage relationship

This is the phase of the lifecycle where the service is actually delivered. This is where the daily works happen and therefore lasts until the contract is about to expire [8]. During this phase, the processes to ensure the delivery and support of the service are performed. In the manage phase, the management of supplier performance is done, reports are expected to be provided by the supplier to review the performance of the supplier [10]. Reference [7] also pointed out regular communications and meetings as one of the building block in manage. We argue that this building block is also part of the supplier performance management.

Reference [7] defined the Manage phase as the building block of manage issues, variation and disputes. During the delivery of the service, there is a risk that a serious incident may occur, resulting the service to stop and of course bring negative impact for the business. Therefore it is highly important to identify and mitigate the risks in advance. Reference [7] has identified this need in his manage risks and plan contingency building blocks. It is extremely important to not only ensure swiftness of the delivery and support of the service, but also the continuous improvement of the service during the contract period. We argue that it is important for customers to know the actions which need to be taken in order to improve the service. Lastly, since all of the processes for providing the service are performed in the supplier side, customers' need to ensure that the SaaS suppliers are conducting their processes according to the agreed requirements. This can be done through evaluation and audit on suppliers' controls, performance and compliance $[7,10]$.

5. Evaluate, renew or terminate

In this phase the customer take the actions to review the contract and the supplier's performance as a whole [7]. Customers also take actions in reassessing their requirements and assessing other options available in the 
market, to compare with the current supplier $[6,7,10]$. If customer considers the current supplier is the best option then the customer will renew the contract, if not then the termination of the contract phase will be done and the activities in the Business Strategy phase will be then performed again $[6,7,8,9]$.

Table 2 depicts the five phases of the sourcing lifecycle along with the activities that occur within each phase.

Table 2. Sourcing lifecycle phases and activities within

\begin{tabular}{|c|c|}
\hline Phases & Activities \\
\hline $\begin{array}{l}\text { Business } \\
\text { strategy }\end{array}$ & $\begin{array}{l}\text { 1. Define business needs } \\
\text { 2. Define requirements based on } \\
\text { business needs } \\
\text { 3. Identification of risk } \\
\text { 4. Source services appropriately } \\
\text { (sourcing model) } \\
\text { 5. Provides input for the demand } \\
\text { forecasting to the provider }\end{array}$ \\
\hline $\begin{array}{l}\text { Supplier } \\
\text { selection }\end{array}$ & $\begin{array}{l}\text { 1. Preparation of request for proposal } \\
\text { 2. Identification of potential suppliers } \\
\text { 3. Distribution of request for proposal } \\
\text { 4. Determination of criteria } \\
\text { 5. Selection of supplier }\end{array}$ \\
\hline Transition & $\begin{array}{l}\text { 1. Preparation of contractual } \\
\text { documents. } \\
\text { 2. Prepare Negotiation Strategy and } \\
\text { Prioritize Negotiation Items } \\
\text { 3. Conduct Effective Negotiations } \\
\text { 4. Finalize and mobilize all plans (e.g. } \\
\text { communication, risk, setup, } \\
\text { acceptance) } \\
\text { 5. Manage the transfers ( work-in- } \\
\text { progress, 3rd party contracts, etc) } \\
\text { 6. Manage the knowledge retention and } \\
\text { transfer } \\
\text { 7. Finalization and Contract Signature } \\
\text { 8. Implement retained organization and } \\
\text { contract management } \\
\text { 9. Conduct acceptance, closeout and } \\
\text { post-implementation review }\end{array}$ \\
\hline $\begin{array}{l}\text { Manage } \\
\text { Relationship }\end{array}$ & $\begin{array}{l}\text { 1. Deliver Service reporting } \\
\text { 2. Strategic review meeting } \\
\text { 3. Tactical review meeting } \\
\text { 4. Manage risk, issues, and escalations } \\
\text { 5. Plan and effect continuous } \\
\text { improvement } \\
\text { 6. Evaluate and audit supplier } \\
\text { (controls, performance, compliance) }\end{array}$ \\
\hline $\begin{array}{l}\text { Evaluate, } \\
\text { renew or } \\
\text { terminate }\end{array}$ & $\begin{array}{l}\text { 1. Asses next generation option (back } \\
\text { source, retain, handover) } \\
\text { 2. Asses contract outcomes and lessons } \\
\text { 3. Knowledge refreshment (e.g. } \\
\text { market, technology, metrics ,price) } \\
\text { 4. Re-asses requirements - re-scope, } \\
\text { re-bundle and re-design } \\
\text { 5. Determine the strategy and business } \\
\text { case for each option }\end{array}$ \\
\hline
\end{tabular}

\section{Different Characteristic of SaaS, Managed Service and ASP}

Based on the definition from [3- 4, 12-15] on SaaS, ASP and Managed Service, [11] explained the different characteristic of SaaS depicted in Table 3 to help highlighting the different focuses that may occur in the SAAS sourcing lifecycle when compared to other sourcing lifecycle.

Table 3. Different characteristics of SAAS, ASP and Managed Service [11]

\begin{tabular}{|c|c|c|c|}
\hline Items & SaaS & ASP & $\begin{array}{c}\text { Managed } \\
\text { Service } \\
\end{array}$ \\
\hline $\begin{array}{l}\text { Delivery } \\
\text { Environment }\end{array}$ & Internet & $\begin{array}{l}\text { Client-server } \\
\text { application, } \\
\text { usually } \\
\text { through } \\
\text { internet }\end{array}$ & $\begin{array}{l}\text { Either } \\
\text { internet or } \\
\text { not }\end{array}$ \\
\hline IT Support & $\begin{array}{l}\text { Inclusive, } \\
\text { Included as } \\
\text { part of } \\
\text { service }\end{array}$ & $\begin{array}{l}\text { Exclusive, } \\
\text { internal } \\
\text { monitoring, } \\
\text { depending on } \\
\text { the degree of } \\
\text { customization } \\
\text { and } \\
\text { integration, } \\
\text { added } \\
\text { maintenance } \\
\text { needs }\end{array}$ & $\begin{array}{l}\text { Exclusive, } \\
\text { internal } \\
\text { monitoring, } \\
\text { depending on } \\
\text { the degree of } \\
\text { customization } \\
\text { and } \\
\text { integration, } \\
\text { added } \\
\text { maintenance } \\
\text { needs }\end{array}$ \\
\hline $\begin{array}{l}\text { Multi-tenant } \\
\text { scalability }\end{array}$ & $\begin{array}{l}\text { Shared (one } \\
\text { to many } \\
\text { model) }\end{array}$ & $\begin{array}{l}\text { Dedicated } \\
\text { (one to one } \\
\text { model) and } \\
\text { Shared (one } \\
\text { to many } \\
\text { model) }\end{array}$ & $\begin{array}{l}\text { Dedicated } \\
\text { (one to one } \\
\text { model) }\end{array}$ \\
\hline $\begin{array}{l}\text { Application } \\
\text { Ownership }\end{array}$ & Provider & Provider & Provider \\
\hline $\begin{array}{l}\text { Infrastructure } \\
\text { Ownership }\end{array}$ & Provider & Provider & Customer \\
\hline $\begin{array}{l}\text { Management } \\
\text { Location }\end{array}$ & $\begin{array}{l}\text { Off } \\
\text { premises }\end{array}$ & Off premises & $\begin{array}{l}\text { On premises } \\
\text { and Off } \\
\text { premises }\end{array}$ \\
\hline $\begin{array}{l}\text { Payment } \\
\text { Type }\end{array}$ & $\begin{array}{l}\text { Usage- } \\
\text { based } \\
\text { subscription }\end{array}$ & $\begin{array}{l}\text { License / } \\
\text { Annual } \\
\text { subscription }\end{array}$ & $\begin{array}{l}\text { Usage-based } \\
\text { subscription }\end{array}$ \\
\hline $\begin{array}{l}\text { Operational } \\
\text { cost }\end{array}$ & Low & Moderate & $\begin{array}{l}\text { Moderate to } \\
\text { high }\end{array}$ \\
\hline $\begin{array}{l}\text { Degree of } \\
\text { customization }\end{array}$ & Low & Moderate & High \\
\hline
\end{tabular}

\section{Case Study}

The case study for this research is a project within a company where a project had been set up to consider SAAS outsourcing model for one of their learning and training application need. In this research, we gathered information from multiple sources such as documents reviews and interviews. The findings are also seen taking place in the case study itself. After conducting the interviews, we interpreted and summarized the findings and sent the summary to the interviewers to get confirmation of the interview results. The result of this 
research, SaaS Sourcing Lifecycle, has been reviewed by the project members and has also been approved by the project committee. This approval led to communication sessions on SaaS Sourcing Lifecycle being conducted to share the result of this research to the wider area of the company. The SaaS Sourcing Lifecycle has also been successfully applied to one of the services outsourcing.

\section{Conclusions}

Although the phases of SaaS sourcing lifecycle are similar with other type of outsourcing life cycle, there will be more focus and time needed for some phases as discussed below and shown in figure 1 .

1. Business Strategy and Supplier Selection In other type of outsourcing models such as managed service, risks can always be managed within the various sub processes in the latter phases. In situations where the application services are delivered via SaaS model, it is important to note that risks will be managed most effectively at the Business Strategy and Supplier Selection phase. The risk mitigation for SaaS delivered applications will shifts forward to the Business Strategy phase and Supplier Selection phase of sourcing lifecycle. Therefore we expect the duration for Business Strategy and Supplier Selection Phase in a SaaS Sourcing Life Cycle will be more stretched than other types of outsourcing.

2. Transition

A SaaS application is a standard application generally shared with multiple tenants, therefore there will be no extra work needed to build a new application like what we may found in other types of outsourcing. This phase duration will be mostly used for the integration activities of the SaaS application with the current applications. Therefore the duration of this phase is expected to be shorter than other types of outsourcing models.

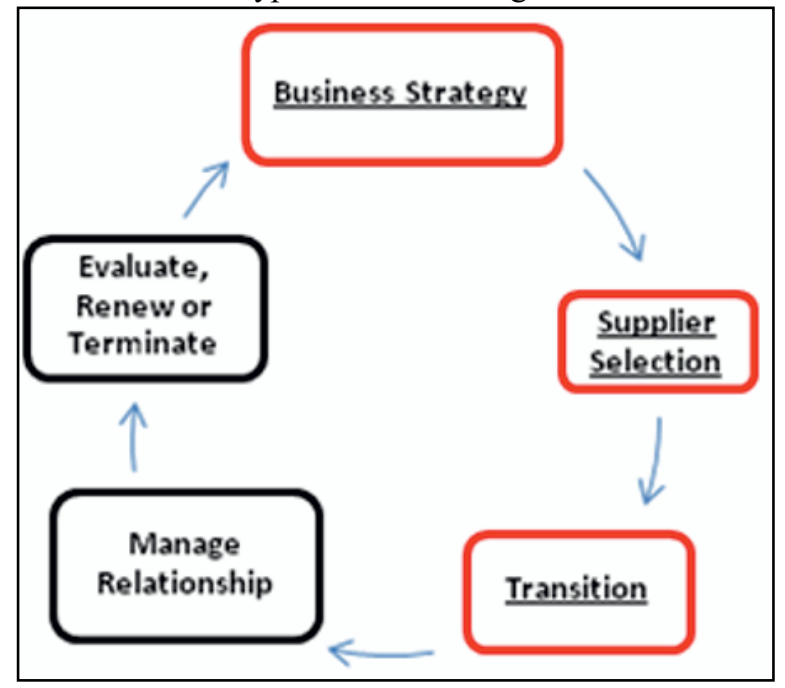

Fig 1. Software as a Service (SAAS) Sourcing Lifecycle.

Along that we also discuss the differences of the SaaS sourcing lifecycle when compared with other sourcing lifecycle where we argue that the focus points of the whole lifecycle for SaaS are in the Business strategy, Supplier selection and Transition phase.

We see several areas of improvement which can be done to the SaaS Sourcing Lifecycle as future researches. The first one will be to research on what are the Key Performance Indicators (KPIs) that are applicable for SaaS. These KPIs are important points that need to be incorporated into the Service Level Agreements signed between customer and the SaaS Supplier. Another topic for further research would be on the change management of SaaS implementation. Change management could easily be a challenge in SaaS implementations within companies who usually can have all types of the control they want. Implementing SaaS model means companies need to let go of these controls to the suppliers, so change management is indeed important to convince the stakeholders about SAAS and help to ensure a smooth run and maintain condition during the contract period.

\section{References}

1. W. Wu, L.W. Lanb, Y. Lee, Int. J.of Inf. Mgt, 31, 556-563 (2011)

2. S. Lee, S. Chaeb, K. Chob, Int. J.of Inf. Mgt, 33, 429-440 (2013)

3. Gartner, "Essential SaaS Overview and 2009 Guide to SaaS Research" (2009)

4. J. Lee, J. Lee, D. Cheun, S. Kim, 2009 Seventh ACIS Int. Conf. on Soft. Eng. Res., Mgt and App, 261-266 (2009)

5. N. A.. Sultan, Int. J. of Inf. Mgt, 31, 272-278 (2011).

6. RL.Kliem, Inf. Sys. Mgt., 16: 3, 91-93 (1999)

7. S. Cullen, , P. Seddon, , L. Willcocks, MIS Q. Exec, 4:1, 229-246 (2005).

8. F. De Jong, "The Right Governance Framework for Managing an Offshore IT Outsourcing Relationship", University of Twente, (2008).

9. R. Hirschheim, A. Heinzl, J. Dibbern, Glob. Chllngs. and Proc. Opps", Springer (2009).

10. W. Au, H. Leung, K. Chan, M. Li, AMCIS 2001 Proceedings. Paper 357, (2001)

11. Santy, "Sourcing Lifecycle for Software as a Service (SAAS) Implementation Shell Case", University of Twente (2010)

12. I. Menken, "SaaS - the Complete Cornerstone Guide to Software as a Service Best Practices Concepts, Terms, and Techniques for Successfully Planning, Implementing and Managing SaaS Solutions". Emereo Pty Ltd., (2008)

13. H. Liao, C. Tao, In Proceedings of the 2008 international Conference on Management of E-Commerce and $E$ Government, (October 17 - 19, 2008). ICMECG. IEEE Comp. Soc., 215-220 (2008)

14. M. A.. Smith, R. L. Kumar, Inf. Manage. 41, 8, 977-1002 (2004)

15. C. Bennett, G. T. Timbrell, Inf. Sys. Frontiers 2, 2 (Aug. 2000), 195-211 (2000) 